\title{
KINGDOM OF SAUDI ARABIA GEOSPATIAL INFORMATION INFRASTRUCTURE - AN INITIAL STUDY
}

\author{
Sultan H. Alsultan a and Alias Abdul Rahman ${ }^{\mathrm{b}}$ \\ ${ }^{a}$ College of Agriculture and Veterinary Medicine, Qaseem University, Buraydah 52571, Saudi Arabia. - comput321@gmail.com \\ ${ }^{\mathrm{b}}$ GII Research Group, Department of Geoinformation, Faculty of Geoinformation and Real Estate, Universiti Teknologi Malaysia \\ Johor Bahru, Malaysia. - alias@utm.my
}

KEY WORDS: National geospatial centre, National standards and policies, National initiative, Strategic plan

\begin{abstract}
:
This paper reviews the current Geographic Information System (Longley et al.) implementation and status in the Kingdom of Saudi Arabia (KSA). Based on the review, several problems were identified and discussed. The characteristic of these problems show that the country needs a national geospatial centre. As a new initiative for a national geospatial centre, a study is being conducted especially on best practice from other countries, availability of national committee for standards and policies on data sharing, and the best proposed organization structure inside the administration for the KSA. The study also covers the degree of readiness and awareness among the main GIS stakeholders within the country as well as private parties. At the end of this paper, strategic steps for the national geospatial management centre were proposed as the initial output of the study.
\end{abstract}

\section{INTRODUCTION}

A GIS can be defined as a computer and digital based application capable of performing virtually any conceivable operation on geographic information, starting from data acquisition, data processing, data visualization, query, and analysis for modelling, sharing, and archiving purposes (Longley et al., 1999,2010; Goodchild, 2012). On the other hand, Goodchild (2012) defined geographic information as information linking locations on or near earth's surface to their properties, characteristic and phenomena at those location. While a geospatial centre refers to a large array of geospatial and GIS related services (see Waterloo, 2015). It can be either for regional based administration, individual organization, state, national or global level. The centre enable to collect, acquire datasets for other stakeholders as well as to share and deliver geospatial services to public, private, within government or to other countries. Geospatial centre at national level however normally deals will several tasks; data collection and standards from other stakeholders, technology on geospatial information, research and development (R\&D), promoting the integrated geospatial data and services, data security and policies or/and others. In service oriented platform, nowadays geospatial centre normally known as Geospatial Information Infrastructure (GII).

This paper is divided into five sections. The second section discusses about the current geospatial status in the KSA (including government, industry and academia) and some arising problems on the current implementation. Then, section three presents the initial finding of the study including the best practice of geospatial implementation at national level, current established programs in the KSA dealing with SDI and geospatial clearing house, status of R\&D for the kingdom and proposed framework of national centre. Section four deals with discussion and analysis while the last section describes on the conclusion.

\section{CURRENT GEOSPATIAL STATUS IN SAUDI ARABIA}

The current implementation of GIS in the KSA either in government or private organizations are based on individual or locally hosted by a particular organization. There are several main organizations that drive the GIS implementation within the kingdom.

\subsection{Geospatial Industries}

\section{General Commission for Survey (GCS)}

GCS was established in 2006 as a corporate body under Ministry of Defence. This agency strives to be the benchmark organization for survey, mapping, geographical information and hydrography in the Kingdom of Saudi Arabia. There are some related strategic objectives of GCS such as produce maps, GIS information (including aerial photography), standards and promoting the use of spatial information for public and stakeholders (GCS, 2015). There are two main GIS projects or programs handled by GCS;

- National Committee for GIS (NSDI)

- Geospatial Information Dissemination (GID)

\section{Local Authority}

The term local authority is not a practice in Saudi Arabia; but rather known as governance, municipal or region (e.g. ArRiyadh Region and Jeddah Municipality). Every municipality has their own jurisdiction and/or authority to implement GIS (or not); either in each department or as centralized GIS for their region such as in Fig. 1. Some municipalities also received international and national recognition and award as for example ISO 9001: 2008 in GIS (Municipility, 2015). 

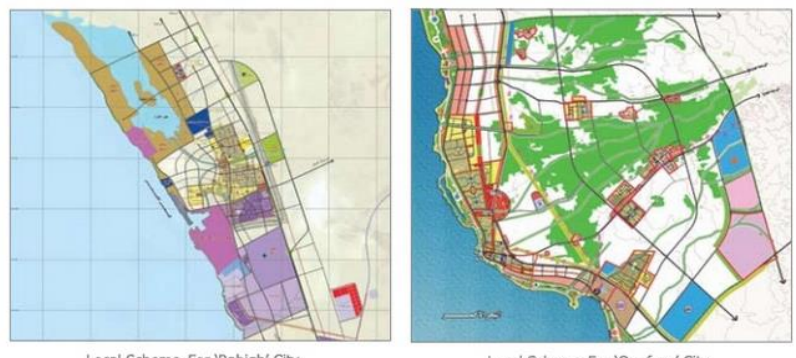

Local Scheme For 'Rabigh' City

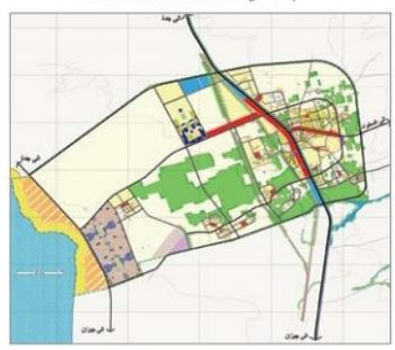

Local Scheme For 'Qunfuzz' City

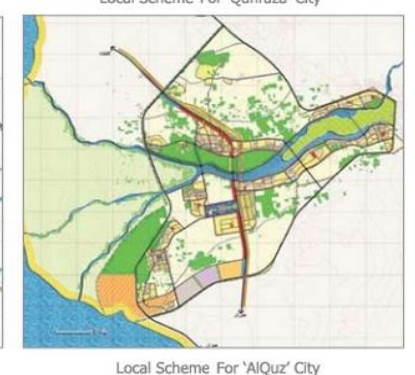

Local Scheme For 'AlQuz' City

Fig. 1: Example of GIS datasets in Province department within Jeddah Municipality (Municipility, 2015).

\section{Private Companies}

Geographic Technologies Trading (GTT) is one of the leading companies for GIS projects (GTT, 2015) such as:

- Al Madinah Spatial Data Infrastructure (NSDI) at Madinah Development Authority

- King Abdullah Project for Waad Al-Shamaal Industrial City

- $\quad 3 D$ As Built Documentation Using Laser Scanning for the Holy Mosque in Makkah

- $\quad$ E-Dig Application for Jeddah Municipality (v1 \& v2).

Apart from GTT, CAD \& GIS Co. Ltd. and Geo Tech Group also provide most of GIS services around the kingdom. The list of their respective projects can be seen in their websites at (CAD\&GIS, 2015) and (GTG, 2015).

\section{Others}

The Saudi Arabian Oil Company (Saudi Aramco) is a stateowned oil company of KSA. Saudi Aramco uses GIS in assets management include wells, pipelines, plants and buildings, roads, utility networks, jet aircrafts, and super-tankers. GIS is being utilised by the company for refining and also for sales operations especially in North America, Europe, and Asia (ESRI, 2007)

Health Geographic Information System web portal has been launched as the early implementation initiatives within Ministry of Health. With the aim to provide an online services providing information and guidance for health facilities and basic related map queries as shown in Fig.2. To broader the GIS applications in health, Murad (2004) had discussed the potential of a creating GIS application for local health care planning in Saudi Arabia. He identified several tools required for that purpose: 1) Geo-coding; 2) Overlay analysis; and 3) Network analysis. The proposed GIS information includes population density, diabetic patients modelling patient flows, blood pressure, asthma patients and populations (Murad, 2004).

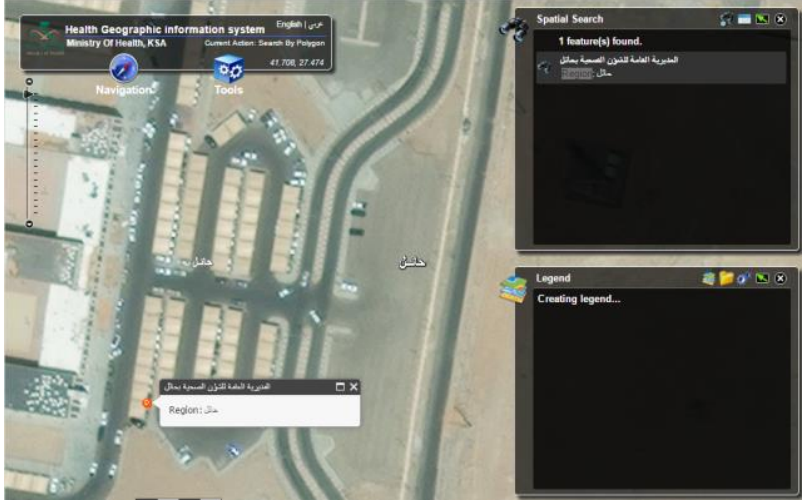

Fig. 2: Health Geographic Information System web portal (MOH, 2013).

Saudi Postal Corporation (Saudi Post) is the governmentoperated postal service for the KSA. In 2010, Saudi Post use GIS as new postal code system to align the postal services with global standards in order to improve their efficiency on mail delivery services (ESRI, 2010).

\subsection{Implementation Problems}

Implementation of individual based GIS in any department of every ministry normally facing drawbacks for geospatial data system integration. Apart from data redundancy, uncertainty of data custodian accuracy, and other problems of decentralizing the same datasets. The study also reveals other typical impediments in the KSA as follow:

\section{Uncoordinated Geospatial Projects}

The individual or agency owned GIS normally resulting uncoordinated GIS-related projects either by itself or GIS contractors. Some projects took a long time to be completed (delayed), e.g. water-based project and drainage construction project in Madinah.

\section{No Standardization}

At this moment, most of the geospatial dataset in Saudi Arabia use different projections that fixed their projects and previous datasets. However, different projections of dataset and standards lead to problem e.g. for sharing data and integrating purposes. Formalized standards on national ISO, national geodetic datum and integration policies should be one of the solutions for the issue.

\section{Other Problems}

There are many problems with regard to the current individually owned geospatial data in the kingdom, including:

- Financial wastage, lack of human resource and space wastage (building);

- $\quad$ Lack of geospatial awareness;

- Economy and development;

- Security and politics;

- Right of information and public services, and

- Professionalism. 


\section{INITIAL STUDY FOR THE KSA}

\subsection{Best Practises at National Level}

A few successful implementations of national geospatial centres were identified as shown in Table 1:

Table 1: Brief comparison on several countries implementation.

\begin{tabular}{|c|c|c|c|}
\hline Country & $\begin{array}{l}\text { National } \\
\text { SDI }\end{array}$ & $\begin{array}{l}\text { Clearing } \\
\text { House }\end{array}$ & Structure \\
\hline $\begin{array}{l}\text { Japan } \\
\text { (GIM, 2015) }\end{array}$ & $\begin{array}{l}\text { Enacted } \\
\text { in May } \\
2007\end{array}$ & $\begin{array}{c}\text { Geospatial } \\
\text { Information } \\
\text { Department }\end{array}$ & $\begin{array}{l}\text { Ministry of Land, } \\
\text { Infrastructure, } \\
\text { Transport and } \\
\text { Tourism }\end{array}$ \\
\hline $\begin{array}{l}\text { Korea } \\
\text { (MOLIT, } \\
2015) \\
\text { (Sakong \& } \\
\text { Kim, 2007) }\end{array}$ & \multicolumn{2}{|c|}{$\begin{array}{l}\text { National GIS } \text { (NGIS) - } \\
\text { since 1995. } \\
\text { 2007) }\end{array}$} & $\begin{array}{l}\text { Integrate most of } \\
\text { the ministry, } \\
\text { especially } M \text {. of } \\
\text { Construction and } \\
\text { Transportation }\end{array}$ \\
\hline \multirow[t]{2}{*}{$\begin{array}{l}\text { Australia } \\
\text { (ICSM, } \\
2015 \text { ) }\end{array}$} & $\begin{array}{l}\text { ASDI - } \\
\text { ICSM }\end{array}$ & $\begin{array}{l}\text { ASDD } \\
(\text { ASDD, } \\
2015) \\
\end{array}$ & $\begin{array}{l}\text { Intergovernmental } \\
\text { committee }\end{array}$ \\
\hline & \multicolumn{3}{|c|}{ Geoscience Australia (Geoscience, 2015) } \\
\hline $\begin{array}{l}\text { USA (NGA, } \\
2015 ; \\
\text { NGCE, } \\
\text { 2015; USGS, } \\
\text { 2015) }\end{array}$ & $\begin{array}{l}\text { NSDI } \\
(\text { NSDI, } \\
2015)\end{array}$ & $\begin{array}{l}\text { Locally by } \\
\text { USGC, NGA } \\
\text { (DOD), } \\
\text { NGCE (DOA) }\end{array}$ & Several ministries \\
\hline $\begin{array}{l}\text { The } \\
\text { Netherlands }\end{array}$ & $\begin{array}{l}\text { PDOK } \\
(\mathrm{PDOK}, \\
2015) \\
\end{array}$ & $\begin{array}{l}\text { National } \\
\text { Georegister } \\
(\mathrm{NGR}, 2015) \\
\end{array}$ & $\begin{array}{l}\text { Initiative from } \\
\text { several ministries }\end{array}$ \\
\hline \multirow{2}{*}{$\begin{array}{l}\text { UK } \\
(\mathrm{SADL}, \\
2011)\end{array}$} & NSDI & & \\
\hline & \multicolumn{3}{|c|}{ One Scotland, One Geography } \\
\hline
\end{tabular}

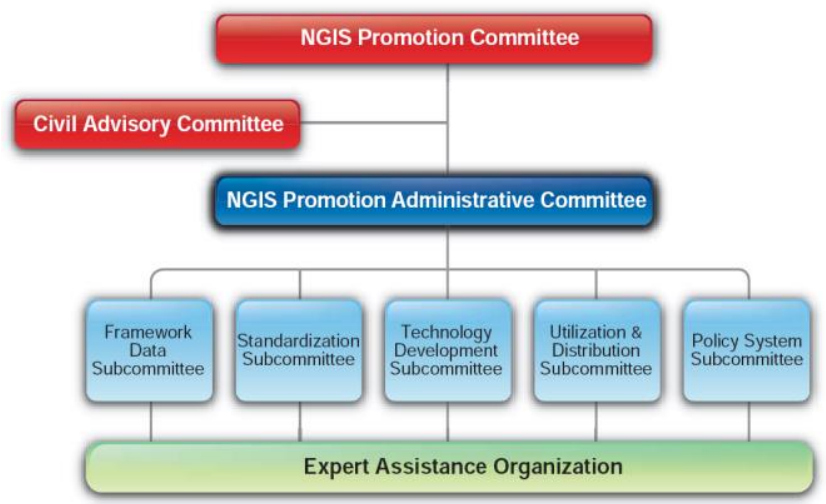

Fig. 3: Korea’s NGIS administration structure (KRIHS, 2007).

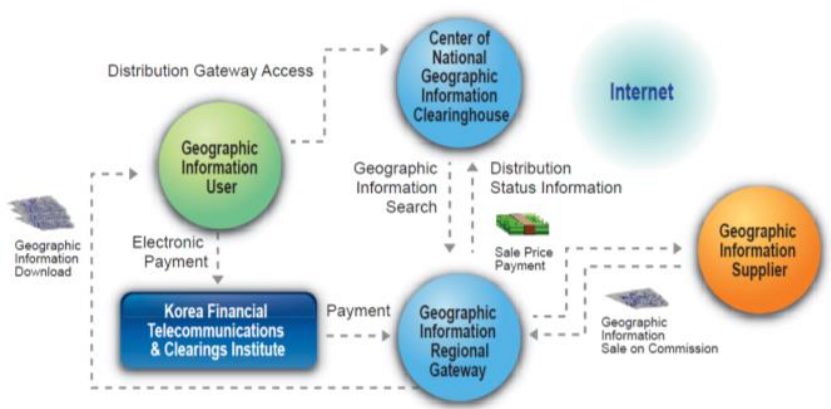

Fig. 4: Component of Korea's NGIS (KRIHS, 2007).

\subsection{Current Established Agencies}

There are two available programs or committees that actively promote and test the geospatial data sharing. They are:

- National Committee for GIS (NSDI):

Pilot implementation phase 1, involved three regions

- Geospatial Information Dissemination : promote integrated geospatial database, SDI, and supporting NSDI

However since the organizations are under a particular ministry and not well coordinated between other parties (except among the shareholders), it is hardly to implement and share the datasets.

\subsection{Geospatial Research}

The establishment of GIS Technology Innovation Center (GISTIC) at King Abdulaziz City for Science and Technology (KACST)'s Umm Al-Qura University (UQU), is the leading in GIS research area. GISTIC is an interdisciplinary technology, innovation, and research center contributing to the effective ways on understanding, managing, analyzing, and visualizing of geospatial phenomena in Saudi Arabia, with the current module on spatio-temporal (GISIF, 2015; GISTIC, 2015). GISTIC also provides their own solution for software (e.g. TAGHREED), hardware (e.g. FAHIM) and application (e.g. TAWA F APP) for the kingdom.

Apart from GISTIC and other local universities, research on Hajj management and traffic movement also be part of national research trend. The municipality need to have traffic awareness plan to avoid traffic congestions during the Hajj (Koshak, 2006).

\subsection{Proposed Framework Structure for National KSA GII Management Centre}

A study on the national geospatial centre for the KSA still at early stage. However, the study plans to focus on the strategic location of administrative structure for the centre, stakeholders, policies and standards for integration of geospatial data and services. The most suitable and proposed place in administrative chart for the centre is directly under Assistance Crown Prince which in parallel with Economic and Development Council.

\section{Stakeholders}

Director of the centre.

All ministries in KSA except two ministries:

- Ministry of Islamic Affairs, Endowments, Calls and Guidance.

- Ministry of Finance

- Saudi General Commission Survey

- Saudi Geological Survey Authority

- Saudi Aramco company

- Saudi Standards, Metrology and Quality Organization

- KACST

- Saudi Post

- Public Railway Agency

- Climatology and Environment Protection Agency

- Flora and Fauna Protection Authority

- Three members from well-established Saudi Arabia GIS companies.

- $\quad$ Three members (appointed by the Director) 


\section{REFERENCES}

\section{DISCUSSION AND ANALYSIS}

\subsection{Advantages of National Geospatial Management Centre in KSA Structure}

There are a few advantages of implementing national geospatial centre or GII in the KSA, quite different from the other countries. Firstly, handling and monitoring of GIS projects could be properly managed due to good government structure. The executives or ministries need to share and receive the other's parts (geospatial data) as there are among the centre's stakeholders.

Secondly, there will be less administrative regulations and procedures for sharing geospatial dataset as compares to the implementation via few ministries or under a single ministry. Good and high cooperation with all ministries, private companies and as well for institutional fields as they were the stakeholders for the national GII.

\subsection{Degree of Readiness for Implementing Nationa Geospatial Centre}

The questionnaires (i.e. surveys) will be carried out to the potential stakeholders and other private agencies within the KSA. The purpose of this study is to access and give a score on the level of readiness of data sharing and the geospatial data usage. The required accuracy, data types, data sources, analysis, applications (services), data formats, data standards and policies of any stakeholders and users also in the pipeline.

\subsection{Strategic Steps}

There are a few strategic steps that can be introduced for the future KSA National Geospatial Information Management Centre for GII establishment. They are:

i. Establish standard formats (e.g. ISO, OGC) and geospatial policies.

ii. Integrate all provinces database as one, including within a province and provide online geospatial services.

iii. Introduce geospatial education in high school and tertiary level

iv. Supporting new apps, devices and tools for the Kingdom.

\section{CONCLUSION}

The national geospatial centre or GII is essential in coordinating and integrating the same geospatial data for any country. The current GIS implementations within the KSA are still based on individual/regional/agency based implementation. There are many problems for integration with other agencies as the way to minimize the costs, time, human and building resources.

This paper attempts to review the current scenario in the KSA in geospatial field and the best practice from other countries in order to formulate the best solution framework for the KSA. The initial findings show that a further study need to be carried out specifically to identify several internal impediments, including public opinions, national standards, and policies.
ASDD. (2015). Australian Spatial Data Directory (ASDD).

CAD\&GIS. (2015). CAD \& GIS Saudi Arabia GIS Projects. from http://cad-gis.info/

ESRI. (2007). GIS Best Practices, Enterprise GIS. http://www.esri.com/library/bestpractices/enterprisegis.pdf

ESRI. (2010). Saudi Arabia Implements New Postal Code System Based on GIS Analysis. Winter 2010/2011. http://www.esri.com/news/arcnews/winter1011articles /saudi-arabia.html

GCS. (2015). Kingdom of Saudi Arabia The General Commission for Survey 2015, from http://www.gcs.gov.sa/

Geoscience. (2015). Geoscience Australia from http://www.ga.gov.au/

GIM. (2015, 11/10/2008). National Spatial Data Infrastructure Act (Japan). GIM International.

GISIF. (2015). GIS Innovation Forum 2015 Retrieved August, from http://www.gisinnovation.org/2015/en/default.aspx

GISTIC. (2015). GIS Innovation Center. Retrieved August 2015, from http://www.gistic.org/

Goodchild, Michael F. (2012). Geographic Information Systems Leadership in Science and Technology (Vol. 2: 238245. Thousand Oaks, CA: SAGE.).

GTG. (2015). Geo Tech Group at Saudi Arabia GIS Projects. from http://www.ags-group.com/

GTT. (2015). GTT Saudi Arabia GIS Projects. from http://www.gtt.com.sa/

ICSM. (2015). Australian Spatial Data Infrastructure (ASDI). Retrieved from: http://www.icsm.gov.au/asdi/

Koshak, Nabeel A. (2006). Developing a Web-Based GIS for Hajj Traffic Plan (HajjGIS.Net). Journal Urban Planning Research, Vol. 6(Issues 6).

KRIHS. (2007). Establishment of National GIS of Korea. In Byong-Nam Choe, Moon-Sub Chung, Jay-Il Han, Shun-Hee Han, Jung-Hoon Kim, Kirl Kim, Mi-Jeong Kim, Young-Joo Lee, Ho-Sang Sakong, Ki-Hwan Seo \& Dong-Bin Shin (Eds.), (Vol. Vol. 8).

Longley, A, Paul, Goodchild, Michael F., Maguire, David J., \& Rhind, David W. (1999). Geographical Information Systems: Principles, Techniques, Management and Applications.

Longley, A, Paul, Goodchild, Michael F., Maguire, David J., \& Rhind, David W. (2010). Geographic Information Systems and Science. Third Edition. Hoboken, NJ: Wiley.

MOH. (2013). Health Geographic Information System web portal. Retrieved August 2015, from http://www.moh.gov.sa/en/eservices/geographic/pages /geographicinformation.aspx

MOLIT. (2015). Korea Spatial Data Portal. from http://www.nsdi.kr/eng/index.do

Municipility, Jeddah. (2015). Jeddah Municipility Portal. Retrieved August, 2015, from https://www.jeddah.gov.sa/english/

Murad, Abdulkader. (2004). Creating a GIS application for local health care planning in Saudi Arabia. International Journal of Environmental Health Research, 14(3), 185-199. doi: 10.1080/0960312042000218606

NGA. (2015). National Geospatial-Intelligent Agency. Retrieved August 2015, from https://www.nga.mil/Pages/Default.aspx 
NGCE. (2015). National Geospatial Center of Excellence (NGCE) - United States Department of Agriculture. Retrieved August 2015, from http://www.nrcs.usda.gov/wps/portal/nrcs/main/nation $\mathrm{al} /$ ngce/

NGR. (2015). National Georegisterer. August 2015, from http://www.nationaalgeoregister.nl/geonetwork/srv/en $\mathrm{g} / \mathrm{search}$

NSDI. (2015). National Spatial Data Infrastructure. August 2015, from https://www.fgdc.gov/nsdi/nsdi.html

PDOK. (2015). The Dutch National SDI ( PDOK ) from https://www.pdok.nl/

SADL. (2011). Spatial Data Infrastructures in The United Kingdom : State of play 2011 (K.U.LEUVEN RESEARCH \& DEVELOPMENT SPATIAL APPLICATIONS DIVISION, Trans.).

Sakong, Hosang, \& Kim, Kirl. (2007, June 27-29, 2007). National GIS Policy and Land Management Information Systems in Korea. Paper presented at the "Good Land Administration - It's Role in the Economic Development", International Workshop, Ulaanbaatar, Mongolia.

USGS. (2015). National Geospatial Program. from http://www.usgs.gov/ngpo/

Waterloo. (2015). Geospatial/GIS Services. Retrieved August 2015, from https://uwaterloo.ca/ 